\title{
REPUBLICAN EPISTEMOLOGY AND ISLAMIC DISCOURSES IN TURKEY IN THE 1990S*
}

\section{Introduction}

In the course of the past decade, the question of identity in the Turkish context has acquired an increasing significance. With the emergence of trends which placed the question of identity outside of the official realm, the people who live on this land began to stagger between local and national as well as traditional and modern identities. This has paved the way for the explosion of multiple identities which were stifled earlier by way of attachment to an official, monolithic, absolute Turkish identity that was engineered during the early Republican years. The increasing significance of Islamic discourses accelerated the process of the decentring of the official Turkish identity during this time.

It is interesting to note that such a crisis of the official ideology in Turkey coincides with the weakening of the foundations of modernity in the West. With the decentring of the West and the dissolution of universalism and cultural essentialism of modernity, the European identity has acquired some relativism as well. Accordingly, it is possible to witness the emergence of what Umberto Eco has aptly called "neomedieval" identities. ${ }^{1}$ The weakening of the foundations of modernity had an impact on the modernizing contexts and especially put into question the certainties of Kemalism in Turkey. The following text maintains that the ensuing fragmentation of identities in Turkey is surrounded by motifs of a Republican epistemology. Epistemology refers to theory that investigates the origin, nature, methods, and limits of knowledge. ${ }^{2}$ Republican epistemology

- I would like to acknowledge Langton Baker for his invaluable comments and Menderes Cinnar for sharing with me his insights and for providing me with some of the readings on the Islamic discourses. Nevertheless, the responsibility for the arguments elaborated in this article remains solely with the author.

1 Umberto Eco, Travels in Ayperreality (San Diego, New York, London: Harcourt, Brace Jovanovich, 1986), 73.

2 The notion of epistemology, here, is used in the Mannheimian, historicist sence, and therefore, tries to cut across the subjectiobject polarity. Historicist theory of knowledge (epistemology) is situated in contradistinction with both an absolutist position based on the truth/ falsity of the contents of knowledge, and a relativist position which envisions a multiplicity of truths and hence, the impossibility of absolutism. The "relationism" of Mannheim's theory of knowledge, in contrast, is non-evaluative since it maintains that knowledge can be analyzed only in a "given type of historical existence." Republican epistemology, throughout this text, is used in reference to Mannheim's historicist theory of knowledge and hence, does not warrant any truth/ falsity in terms of the contents of knowledge, but is rather non-evaluative. See, Karl Mannheim, Ideology and Utopia (San Diego, New York, London: A Harvest HBJ Book, 1936), esp. 86. 
has two distinguishing features. First of all, it is based on an essentialist distinction on the part of the Republican elite between the East and the West, and/or the Orient and the Occident. The knowledge of the Republican elite about the world is constructed on such an essentialist distinction between the authentic self and the privileged other (the civilized West). Such an epistemology finds its origins in the Ottoman statesmen's initial encounters with the West as the Other and in their efforts to carve out a modern identity in the course of the nineteenth century. Such essentialist foundations of knowledge reached a climax in the early Republican years that found an expression in the project of secularization. In sum, Republican epistemology refers to a modernist trend that inherently embraces an essentialist distinction between the self and the privileged other. Secondly, it is based on a managerial attitude on the part of the Republican elite who identify civilization as a societal goal and from that point onwards unleash processes of social engineering geared towards constructing a modern national identity at the expense of traditional, local, religious identities. In sum, the distinguishing features of the Republican epistemology are essentialism and the ensuing constructedness of social phenomena. One of the key points of the following text is its acknowledgment of a similar essentialism and constructedness within the Islamic discourses that purport to challenge the official Republican Turkish identity.

Although constructedness of social phenomena is a feature of all societies in the process of carving out a modern identity, some non-Western modernizing contexts such as Turkey display a severing of links with past traditions. One of the paradoxes of modern nations is that they generally claim to be natural human communities rooted in antiquity whereas they have a constructed, novel component. ${ }^{3}$ Modern national identities are constructed by a high culture at the expense of local, fragmented low cultures. ${ }^{4}$ Hence, with the advent of industrialization and the construction and/or "invention" of modern national identities, there begins the process of separation of the modern, rational self of the high culture and a low culture which lacks what the modern self has. This results in the delinking of the modern, central, urban cultures and the traditional, peripheral, rural cultures. At the international level, the perpetuation of such binary logic results in a process of othering which was aptly described by Edward Said as the "Orientalization of the Orient." ${ }^{5}$ Accordingly, the Orient was Orientalized by virtue of a relationship of power, of domination between the West and the East. As Said puts it: Orientalism "fairly stands

3 Eric Hobsbawm and Terence Ranger, The Invention of Tradition (Cambridge: Cambridge University Press, 1983), 14.

4 Ernest Gellner, Nations and Nationalism (New York: Cornell University Press, 1983).

5 Edward W. Said, Orientslism (New York: Vintage, 1979), 5. 
for the pattern of relative strength between East and West, and the discourse about the Orient that it enabled." 6

It is, then, possible to refer to an "invented tradition" as a distinguishing feature of modernity in all societies, Western and non-Western. According to Hobsbawm:

Invented tradition is taken to mean a set of practices, normally governed by overtly or tacitly accepted rules and of a ritual or symbolic nature, which seek to inculcate certain values and norms of behavior by repetition, which automatically implies continuity with the past. In fact, where possible, they nor mally attempt to establish continuity with a suitable historic pas? (italics mine).

Still, the invention of tradition acquires a distinct characteristic in the non-Western modernizing contexts since this may not imply a continuity with past traditions. Contrary to the processes in the modern, Western contexts where an attempt to establish continuity with a suitable historic past is considered "normal" by Hobsbawm, in the modernizing, nonWestern contexts, the process of invention of tradition involves a break, a discontinuity with the past. Such a discontinuity with the past lies behind the state of amnesia which has prevailed in Turkey ever since the foundation of the Republic in the early $1920 \mathrm{~s}^{8}{ }^{8}$ This is an implication of what is referred to as the Republican epistemology in the Turkish context in the following pages.

In what follows, first of all, the initial efforts towards constructing a modern Turkish identity during the mid-nineteenth century, which prompted the politicization of Islam, will be portrayed. Secondly, the Republican efforts towards establishing an official Turkish identity will be discussed with special reference to quite distinct policies of secularization. In the last part, the discourses of the three Islamic groups in Turkey, namely, the political Islamists organized around a political party, Muslim intellectuals, and a community of moderate Islamists will be evaluated by way of reference to the Republican epistemology.

\footnotetext{
6 Tbid., 6.

7 Hobsbawm and Ranger, The Invention of Tradition, 1.

8 Such a state of amnesia warrants a rewriting of Turkish history by re-establishing severed links with the past, i.e. a process of societal psychotherapy which seems imminent in the current debates that try to come to grips with the decomposition of identities. See Ayşe Kadioğlu, "Milletini Arayan Devlet: Türk Milliyetçilił̧inin Açmazlari,' Türkiye Gün/üğä 33 (1995): 91101.
} 


\section{Progress for the Sake of Order: Tanzimat and Encounters with the West}

Ever since the beginnings of modernization of the Ottoman institutions in the course of the eighteenth century, the primary goal of the modernizers had been the preservation of the state. Modernization attempts started within the military institution and were geared towards establishing disciplined troops trained in accordance with the recommendations of Western military advisors. At the turn of the nineteenth century, modernization involved areas other than the military as well. The Tanzimat Reforms, which were introduced by the Tanzimat Charter in 1839, involved a major reorganization at the levels of provincial administration, education and the judiciary. Tanzimat-as the term indicated-involved the restructuring and re-ordering of the fundamental institutions of the Ottoman system. Still, all the institutional novelties of the Tanzimat were geared towards preserving the existing order, i.e. nizam-i alem. ${ }^{9}$ Hence, first of all, it is possible to argue that modernization was introduced within the Ottoman state system at the turn of the nineteenth century for the sake of preserving order. Secondly, with the introduction of modernization, the predominant debates of the time focused on the limits of that modernization. The extent and degree of modernization constituted the main problematique of the Tanzimat era.

Starting with the Tanzimat reforms, there began the Ottoman statesmen's encounters with the West that shook the fundamental premises of the old Ottoman order (kanun-u kadim). The traditional millet system, based on religious stratification of the Muslims and non-Muslims, began to be dismantled in the course of the Tanzimat reforms. The reforms pertaining to the equality of the Muslim and non-Muslim peoples (müsavat) crystallized in the Reform Edict of 1856 (Islahat Fermani). The Reform Edict promised full equality to the non-Muslims which included equality in liability for military service as well as for entry to government positions and schools. ${ }^{10}$ According to Niyazi Berkes, the Reform Edict of 1856 involved more concrete measures geared towards continuing a modernist trend that was set by the Tanzimat Charter. ${ }^{11}$ Since such measures affected the day to day activities of the people, it generated a major uproar in the society. The Reform Edict of 1856 and its implications symbolized the deepening of a rupture between the Muslims /millet-i hakime) and the non-Muslims (millet-i mahkume) within the empire.

9 Mehmet Ali Kìliçbay, "Tanzimat Neyi Tanzim Etti," Argos, 15 November 1989, 57-63.

10 Stanford J. Shaw and Ezel Kural Shaw, History of the Ottoman Empire and Modern Turkey (Cambridge: Cambridge University Press, 1994), II: 100.

11 Niyazi Berkes, Türkiye'de Cagdaslassms (Istanbul: Doğu-Bati Yayinlarĩ, 1978), 211. 
Behind the Reform Edict of 1856 lay the Tanzimat statesmen's eagerness to establish amiable diplomatic relations with the Western powers. The issue of the equality of the Muslim and non-Muslim peoples was one of the crucial items which was on the list of preconditions of the European powers for establishing such relations with the Ottomans. The Edict itself was prepared by a commission of representatives from England, France, Austria, and the Ottoman state. According to the provisions of the Edict, the Ottomans promised the Western powers to end the distinctive and discriminatory head tax which was placed on the non-Muslims. Instead, a simple military-service tax was imposed on non-Muslims who were liable for conscription under the law. The military-service tax was less than the equivalent tax imposed on Muslims for exemption. ${ }^{12}$ Such measures prompted an uproar among the Muslims within the empire who felt that the ground beneath them was increasingly becoming more slippery and that they were losing their old privileged status. According to Türkōne, the Reform Edict of 1856 and the issue of equality of the Muslims and non-Muslims created a feeling of resentment among the Muslim populace and was expressed in the writings of the Young Ottomans who referred to the edict as the Edict of Privileges (Imtiyaz Fermani). ${ }^{13}$ Hence, the reaction to the Reform Edict was a driving force of Islamism in the Ottoman society. ${ }^{14}$

With the triggering of ethnic nationalisms within the empire and the efforts at modernization prompted by Tanzimat statesmen in order to preserve the state, the premises of the established Ottoman order were greatly shaken. By the middle of the nineteenth century, it became clear that the question of identity emerged in the Ottoman empire as a result of the Tanzimat reforms which dismantled the old order and along with it old communal, provincial identities which were in accordance with the Ottoman millet system. It was at this particular historical juncture that the need to construct a modern identity for the Muslim peoples of the empire emerged. The move from a given to a constructed social environment accompanied the Ottomans' encounters with the West which came to be viewed as the privileged Other. The efforts of the Ottoman intellectuals in the context of this movement from given to constructed identities crystal-

12 Shaw and Shaw, History of the Ottoman Empire and Modern Turkey II: 100.

13 Mümtaz'er Türköne, Siyasi Ideoloji Olarak Islanciliğin Doğusu (Istanbul: Iletişim Yayinlarì, 1994), 68. Türköne reviews The reactions of Ziya Paşa (1825-1880). Namik Kemal (1840-1888). and Ali Suavi (1838-1878) to the Reform Edict of 1856.

14 Ibid., 71. See also 67-68, where Türkone points to the emergence of a secret organization in Istanbul in 1859 as a response to the Reform Edict of 1856 . This organization was based on Islamic premises and was the driving force behind the Kuleli incident that was geared towards reinstituting an order based on seriat. The attempted coup initiated by the members of the organization led by Seyh Ahmed failed. Yet, the Kuleli incident revealed the seeds of political Islam in the aftermath of the Reform Edict of 1856. 
lized in the social engineering projects of Ottomanism (Ittihad-i Osmani), Islamism (Ittihad-i Is $/$ am), and finally Turkish nationalism (Ittihad-i Etrak) with the activities of the Young Turks and the Committee of Union and Progress at the turn of the twentieth century.

The Tanzimat reforms opting for modernizing the established traditional structures produced the dual categories of Tanzimat thought. These dual categories were quite akin to the dual categories of modernization theory which established the practice of studying societies as two, idealtypical polar types, namely traditional and modern. Accordingly, traditional came to represent a residual category, an Other, defined by way of reference to a privileged, modern Self. With the beginnings of modernization in the Ottoman empire and encounters with the West, it is possible to observe the establishment of an essentialist thought structure which was based on the dual categories of Occident-Orient, West-East, Modern-Traditional, Civilization-Culture, Science-Religion. This process involved the reproduction of the dual structures of modernity in the modernization context. It was accompanied by an effort to construct a novel, modern identity on the part of the Ottoman intelligentsia.

Accordingly, the distinguishing feature of the modernization context involved placing the cart before the horse, i.e. the adoption of Western institutions before the realization of an epistemological transformation in the society that would produce a demand for them. Hence, the process of Enlightenment in the West became a project in the context of Turkish modernization. This resulted in the process of delinking from the past traditions which in turn became the major cause of the separation between the elite and the mass cultures within the Ottoman society at the end of the nineteenth century. The Republican elite perpetuated these trends by starting a process of secularization and along with it the construction of a secular, national identity.

\section{Order for the Sake of Progress: The Republican Project of Modernization}

The Republican efforts at modernization were much more pronounced than the ones in the Tanzimat era. The Republican elite undertook a project of wholesale Westernization. Since there was no radical philosophical rupture from established thought patterns similar to the process of Enlightenment in the European context, Enlightenment was constructed from above in the Republican context, i.e., it became a project. An evaluation of the nature of the Republican secularization is crucial in understanding the constructed nature of the Republican reality.

There is considerable disagreement in the literature as to whether the notion of din $u$ devlet (religion and the state) connotes the existence of a 
theocratic structure within the Ottoman empire. In a highly stimulating article on the nature of Turkish secularism, Nur Vergin aptly underlines the lack of an agreement among the students of the subject regarding the theocratic nature of the Ottoman state. ${ }^{15}$ Vergin maintains that the existing evidence is not adequate to point to the theocratic nature of the Ottoman state. She rather refers to the dialogue, and the blissful coexistence of state and religion in the Ottoman system. It is not the purpose of this text to review or to evaluate the debates regarding the existence or lack of a theocratic structure within the Ottoman system. Rather, it is sufficient ta point to the implications of such differing views on the current secularism debates. While a conviction regarding the theocratic structure of the Ottoman system justifies the adoption of the Republican secularization attempts, analyses that question such a conviction regarding the Ottoman system open up new avenues for establishing a continuity between the current state of the Republic which is plagued by clashes of the secularist and Islamist camps and the Ottoman past. Binnaz Toprak's analysis of secularization in the Turkish Republic, for instance, largely draws upon the former conviction. ${ }^{16}$ It is largely based on an axiomatic proposition regarding the impossibility of separating the religious realm from the secular one in Muslim societies because of the nature of Islam. This paves her way to saying that:

... if separation of Islam and politics seemed difficult, then the former at least could be made subservient to the latter. Hence, religious institutions were linked to the state bureaucracy rather than to create an autonomous organization. ${ }^{17}$

Contrarily, analyses-like Vergin's-that question such an axiomatic proposition regarding the unity of state and religion in Islam can perhaps be distinguished as an effort at inventing tradition and/or belated invention of tradition in the post-Republican era.

It is clear to any student of Turkish politics that the Republican project of secularization did not involve a separation of state and religion in the Lockean sense of the word. John Locke (1632-1704) formulated the classical liberal position on secularism as follows:

Political society is instituted for no other end but only to secure every man's possession of the things of this life. The care of each man's soul, and of the things of heaven, which neither does belong

15 Nur Vergin, “Din ve Devlet Llişkileri: Düșūncenin 'Bitmeyen Senfoni’si," Türkiye Gün/üğü 29 (1994): 5-23.

16 Binnaz Toprak, Islam and Political Development in Turkey (Leiden: E.J. Brill, 1981).

17 Ibid, 33. 
to the commonwealth nor can be subject to it, is left entirely to every man's self. ${ }^{18}$

Locke had a view of religion as an entirely private matter and churches as voluntary associations.

The Republican Turkish secularism was more akin to the French secularist model which was knitted by Comtean, positivist motifs. By the middle of the nineteenth century, French philosopher Auguste Comte (1798-1857) developed the basic premises of Positivism. ${ }^{19}$ Comte believed that history progressed from theological, to metaphysical, to positive modes of thought and related types of social organization. Accordingly, Comte fostered a view of progress by turning away from theology and abstract speculation towards the scientific study of nature and society. He foresaw analyses of societies by utilizing natural science methods of empirical observation which would pave the way to an evolution under the supervision of specialists or social engineers. All in all, Comtean positivism fostered both social engineering and evolutionism, which came to be symbolized in its motto: Order and Progress.

In fostering social engineering, positivism turned into a project. Positive philosophy, while advocating a turn away from theology and abstract speculation, instilled a trend which substituted a secularized, human religion in place of theology. In this new secular religion, otherworldly God is replaced by humanity. With the advent of Comtean Positive philosophy, medieval theology is replaced by contemporary sociology. ${ }^{20}$ Comte held an instrumental view regarding both science and religion. He elevated society and humanity to the level of God and placed science and religion at its service. Perhaps, one of the most significant implications of Positive philosophy was reflected in the secularization policies of the French Third Republic. Vergin points to the significance of the "secularist" (as opposed to secular) policies of the ministers of the French Third Republic who maintained that they would be tolerant towards religious beliefs but would not compromise when it came to the premises of positivism. ${ }^{21}$ Hence, the positivism of the ideologues of the Third Republic fostered policies which were geared towards shaping a non-theological, secular conscience at its schools that were the most common arena of clashes between religious

\footnotetext{
18 Locke's views on the separation of state and religion were expressed in Letter Concerning Toleration (1689) in J.W. Gough, ed., The Second Treatise of Government and a Letter Concerning Toleration (Oxford: Basil Blackwell, 1956), see esp. 155.

19 For a coherent review of Comtean positivism see Russel Keat and John Urry, Social Theory as Science (London: Routledge and Kegan Paul, 1975). See also Auguste Comte, The Positive Philosophy of Auguste Comte, trans. , Harriet Martineau (London: Chapman, 1853).

20 Vergin, "Din ve Devlet llişkileri," 11.

21 Ibid., 14.
} 
beliefs and positivist ideology. ${ }^{22}$ There is no doubt that secularist thought which emanated from Positive philosophy was situated vis $\dot{a}$ vis theology. In fact, it was situated in a privileged position vis à vis theology along the evolutionary trend which would shape the contours of the modernization theories a century later. In doing so, it established secularism as an end. It gave secularism a teleological character. The classical liberal notion of secularism was a means towards private and public happiness. It is exactly at this point that the Lockean and Comtean views differed from each other: while the former represented a view of secularism as a means towards private and public happiness, the latter, secularist view gave secularism a teleological as well as a theological character. It is the latter view which formed the backbone of Kemalist secularization.

\section{Republican Epistemology and Hyperrealism}

Republican reforms aimed at constructing a national identity as well as establishing political legitimacy based on secular appeals. The Republican project of Westernization "showed a clear distaste for religion," ${ }^{23}$ since its founders, caught in positivist motifs, were convinced that Islam was the cause of the backwardness of the Ottomans. Republican reforms prompted a dismantling of the religious establishment while simultaneously constructing secularist arrangements at various levels. With the onset of the modernization of the Ottoman institutions, there began a centralized tendency to construct social phenomena on the part of the Tanzimat statesmen. Later, this tendency culminated in a Republican epistemology with the introduction of the Republican reforms.

With the onset of modernization, and the process of recoiling identities in a world laden with nationalist motifs, the Ottoman and/or Islamic Self came to be identified in reference to a privileged, modern Other, i.e. the West. The literary currents of the late nineteenth century, on the one hand, grappled with the question of constructing a modern national identity in the aftermath of encounters with the West within and outside of the empire, while they tried to portray the compatibility of Islam with modernity, on the other. The prevailing idea of the times was to adopt the "good" aspects of the West such as its technological superiority while

22 The educational establishment still continues to be an arena of clashes between religious beliefs and secularist views in France. In the course of the 1980s, whether the Muslim students wearing the headscarf should be admitted to schools or not was a major source of dispute. Interestingly, a similar dispute erupted between the secularist and religious groups in Turkey at the end of the 1980s and early 1990s.

23 Serif Mardin, "The European Culture and the Development of Modern Turkey," Ahmet Evin and Geoffrey Denton, eds., Turkey and the European Community (Opladen: Leske, Budrich, 1990), 13-23, esp. 21. 
rejecting its "bad" aspects such as its culture and religion. A similar trend was expressed in the separation of Culture and Civilization, the dual notions which the late Tanzimat writers were so keen on synthesizing. ${ }^{24}$ Since such an act of synthesizing involved a construction of social phenomena, it is possible to locate the beginnings of social engineering projects which purported to constitute a modern identity in the Tanzimat era. Such projects included Ottomanism, Islamism, Turkism. Still, the genesis of the Young Ottoman thought, despite the beginnings of an epistemology based on contructedness, contained themes which reflected a continuity with the earlier Ottoman ethos. What distinguished the Republican period was an emphasis on progress, and hence, Westernization. Whereas earlier, progress was mainly acknowledged for the sake of order, the goal of progress and wholesale Westernization was brought to the forefront as the basic goal during the early years of the Republic. The Republican elite, by adopting a view of teleological secularism, unleashed the Islamic bond which kept the Ottoman system intact. In doing so, they started a tradition of discontinuity with the past which culminated in a state of amnesia imbued in the psyche of the "new Turks." 25 The difference of such a route from the "invention of tradition" was explained above. Hence, a tradition of social engineering which began with modernization efforts during the Tanzimat era reached its climax with the Republican epistemology that prompted a rupture from the Islamic past. The evolution of this epistemology starting with the Tanzimat era and its accentuation during the early Republican period portrays the dilemma of progress in the modernization context.

Two consequences of the Republican reforms seem significant in the present context. First of all, by adopting a secularist approach in conjunction with the Republican epistemology, the Republican reforms dismantled the major functions of Islamic arrangements in the society. Serif Mardin maintains that religion performed a double function in the Ottoman empire. While on the one hand it was the most important link between the center and periphery, and hence a reference for the rulers in their relation to the ruled, it also offered mechanisms for social cohesion

\footnotetext{
24 See my account of the significance of the dual notions of Culture and Civilization rooted in the Romantic and Enlightenment philosophies respectively, and how an attempt to synthesize them paves the way to the paradox of Turkish nationalism. Ayse Kadioglu, "The Paradox of Turkish Nationalism and the Construction of Official Identity," Middle Eastern Studies 32 , no. 2 (April 1996): 177-94. Partha Chatterjee points to the way such a paradox accentuates the role of the state in Eastern nationalisms. Partha Chatterjee, Natjonalist Thought and the Colonial World: A Derivative Discourse (Minneapolis: University of Minnesota Press, 1993).

25 The notion "the new Turks" is used by Eleanor Bisbee, an American missionary who describes the Turkish revolution from outside. Eleanor Bisbee. The New Turks. Pioneers of the Republic, 1920-1950 (Philadelphia: University of Pennysylvania Press, 1951).
} 
to the ruled. ${ }^{26}$ Secularist arrangements of the Republic undid the religious bond between the elite and the mass cultures and accentuated the delinking of the center and the periphery in Turkey. This, in turn, furthered the premises of the Republican epistemology which continued to impose from above elite projects which remained alien to the mass culture. The efforts of the Republican elite were geared towards greater centralization in the aftermath of peripheral revolts. Such an attitude on the part of the Republican elite further separated the center and the periphery. For instance, in the period after the Menemen incident, a religious peripheral revolt which took place in November 1930, the Republican elite launched the ideology of Kemalism in accordance with the principles adopted at the Third Party Congress of the Republican People's Party. Accordingly, the six fundamental and unchanging principles of the regime were defined as Republicanism, Nationalism, Populism, Etatism, Secularism, and Revolutionism/Reformism. Moreover, in January 1932, the Republican elite started the publication of a monthly called Kadro which was geared towards creating a Republican ideology.

Secondly, it is important to emphasize that the secularist policies of the Republic which aimed at dismantling the Islamic societal arrangements were, nevertheless, laden with Islamic motifs since Islam constituted the medium of communication between the elite and the mass cultures. $\mathrm{Al}$ though the Republican elite were moved by a disgust towards religion, they sometimes resorted to religious symbols in their behavior. ${ }^{27}$ They resolved the dilemma of the intellectuals in a modernizing context, caught between the urge to Westernize and to retain a pristine identity, by paying lip service to the Islamic symbols. In Chatterjee's words, "the philosopher-kings of the 'underdeveloped' world all act as westernizers, and all talk like narodniks." ${ }^{28}$ Hence, the religious symbols and themes continued to be predominant within the discourse of the Republican elite despite their apparent dislike of Islamic motifs.

Mardin maintains that the Turkish revolution was not the design of a discontented bourgeoisie nor was it prompted by peasant dissatisfaction. It did not have as its target a major infra-structural overhaul. It rather remained as "a revolution of values." 29 The alteration of the symbolic system of society in conjunction with progress was more significant than

26 In fact, Mardin maintains that while elite, orthodox Islam provided the basis of upper class ideology, folk Islam of the dervis orders became the basis of social cohesion of the masses. Serif Mardin, "Ideology and Religion in the Turkish Revolution," International fournal of Middle East Studies 2 (1971): 197-211, esp. 208-9.

27 Mardin compares this disgust of the Republican elite towards religion to Voltaire's hatred of the Church. Mardin, "Ideology and Religion in the Turkish Revolution," 208.

28 Chatterjee, Nationalist Thought and the Colonial World, 4.

29 Mardin, "Ideology and Religion in the Turkish Revolution," 209. 
any blows dealt to the infra-structure. Hence, the Turkish revolution had paved the way to a political culture akin to hyperreality since it contained numerous motifs which looked real, although they were largely manufactured.

The hyperreal condition produced as a result of the nature of the Turkish revolution can best be described by the emphasis laid on images in modern Turkey. I have elsewhere discussed the significance of the fierce disputes between the Islamic turbaned women and secularist, Kemalist women (whom I call modernes de robe) which began to occupy the Turkish political agenda since the second half of the 1980s. ${ }^{30}$ These disputes usually took the form of a fight over costumes and other symbols of Islamist and secularist views. The display of Atatūrk's modern, civil, Western costumes in the Atatürk Mausoleum, the popular naming of western dress tie for men as the "rein of civilization," the various ambivalent styles that Turkish music has taken by a strange dynamics of impositions from above and resistances from the popular culture, ${ }^{31}$ all point to the significance of images, made and unmade, in the Turkish context. The image of modernity has always carried a substantial weight within the Turkish modernization project. Not surprisingly, this has placed Turkish women in the display window of this project. Perhaps, the distinguishing feature of the modernizing reforms was the hyperreal condition that they had produced. This was largely the result of the Republican elite's managerial attitude to the world of images and their urge to construct them in line with their project of wholesale Westernization.

The Islamic discourses in the 1990s, too, pay lip service to the secularist symbols and images just as much as the secularist Republicans utilized Islamic symbols and images. It is interesting to note that the Muslim intellectuals of the 1990s are very much a product of the secularist Republican institutions. They are well trained in secularist concepts as well as Western historiography. Still, the tide has turned to a certain extent since the Muslim intellectuals of the 1990s, as opposed to their Republican counterparts, seem to talk like Westerners but act like narodniks. We now turn to some aspects of the Islamic discourses of the 1990s.

\footnotetext{
30 Ayşe Kadioğlu, "Women's Subordination in Turkey: Is Islam Really the Villain?" Middle East Journal 48, no. 4, (Autumn 1994): 645-61.

31 See, Orhan Tekelioğlu, "Türk Popunun Tarihsel Arkaplani," Toplum ve Bilim 67 (1995): 157-78. See also by the same author, "The Rise of Spontaneous Synthesis: The Historical Background of Turkish Popular Music," Middle Eastern Studies 32, no. 2, (April 1996): 194216.
} 


\section{Islamic Discourses in the 1990s}

Kemalism tried to marginalize as well as to control Islamic institutions. However, this did not lead to the disappearance of Islam from the public realm. It rather paved the way to its politicization. Hence, Kemalism produced a politicization of Islam rather than its secularization. ${ }^{32}$ The Kemalist Westernization project constructed on top of a marginalized Islamic identity contained in itself the seeds of its own destruction. Kemalism turned out to be a modern cul de sac. Accordingly, the more it succeeded, the less able it became to rejuvenate its discourse. While originally, the Kemalist project was based on a split between the modern and traditional cultures, its very success diminished the physical distance between these two cultures. As a result of massive internal migration, big metropoles became the very location where the modern and traditional cultures found themselves in a position to coexist. In short, the more the physical distance between these cultures was lessened the likelihood of a clash between them increased in a context in which Kemalism succeeded in dismantling the integrative role of Islam. Hence it is not surprising that modern metropoles became the locus of the struggle between political Islam and secular Kemalism. Hence, it is possible to say that one of the distinguishing features of political Islam is its rootedness in modernity, and by the same token in an epistemology based on a similar constructedness espoused by the Republican elite. In what follows, such a view of political Islam will be elaborated by referring to the discourses of the Islamic Refah Party (RP), ${ }^{33}$ some Muslim intellectuals, and one of the representatives of what could be called moderate Islam in Turkey, Fethullah Gülen and his community who has increasingly been capturing the attention of the political elites and the media in the course of the past couple of years.

The Refah Party (RP) was founded in 1983 in the aftermath of the military coup of 1980 which suspended the activities of all the former political parties including the earlier Islamic political party, the National Salvation Party (Milli Selamet Partisi). RP seemed to be a continuation of the earlier Islamic parties like the National Order Party (Milli Nizam Partisi) and the National Salvation Party. Yet within a couple of years after its founding it began to portray different features. By the 1990s, RP was already behaving like a modern mass party. Whereas earlier party membership was quite limited to elements which did not aspire to a modern image,

32 Bobby Said, "Sign O'Times: Kaffirs and Infidels Fighting the Ninth Crusade," Ernesto, Laclau, ed., The Making of Political Ydentities (London: Verso, 1991), 264-86, esp. 271.

33 Since there seems to be a disagreement among the students of Turkish politics as to how to translate Refah Party into English, either Prosperity Party or Welfare Party, I choose to stick with the Turkish original. 
in the course of the 1990s the RP leadership, for instance, began to recruit professional women who were uncovered. One of the reasons which prompted such a change within the RP was the modern image that the party leadership had adopted in the 1990s in trying to appeal to a wider electorate. In a way, the RP had begun to go beyond the archaic image given to it by the Kemalist, secularist groups in the society.

$\mathrm{RP}$, at the beginning, was riding on the coattails of the earlier National Order Party and National Salvation Party. The National Salvation Party was especially instrumental in legitimizing Islamic politics in a Kemalist Republic. ${ }^{34} \mathrm{RP}$, then, only had to consolidate that legitimacy. In doing so, it changed its image and adopted a modern style. For instance, it replaced invitation to Islamic ways (tebliğ) with propaganda. Tebliğ involved a criticism of the extent of Muslimness of RP's political opponents. RP, in the 1990s, in contrast, began to base its criticisms of opponents on the weaknesses of the latter's managerial and policy skills rather than the extent of their Muslimness. Hence, a shift from tebliğ to propaganda became one of the facets of the new image of RP which began to voice this worldly promises to its enlarging constituency. ${ }^{35}$

The March 1994 municipal elections was one of the turning points in RP's history. In those elections RP made significant gains, its candidates winning mayoral positions in Turkey's two largest cities, Istanbul and Ankara, as well as in scores of other cities and towns. This seems to have enhanced the move from religious puritanism to modern pragmatism within the RP.

While moving away from an Islamic, closed image of a cadre party to a modern image of a mass party, RP lost some of its anti-state, civil societal characteristics. Originally, the discourse of the RP was based on a criticism of the secularist policies of the Republic, and included the idea of a rejuvenation of the Islamic identity of the Turks. This challenged the monolithic, absolute, official Turkish identity constructed during the early Republican years. Yet, RP in its new modern attire failed to contribute to the deconstruction of identities in Turkey by shifting to a centralized discourse reminiscent of the Republican epistemology. Several activities of the RP leadership during its opposition years in the course of the 1990s point to such a centralization in its discourse as opposed to democratization. First of all, members of parliament from RP voted for the lifting of the judicial privileges of the Kurdish members of parliament who have

\footnotetext{
34 National Salvation 'Party's participation in coalition governments with the secular, system parties in the course of the 1970s was quite important in legitimizing Islamic views in mainstream politics in Turkey. See Ruşen Cakir, Ne Seriat Ne Demokrasi, Refah Partisini Anlamak (Istanbul: Metis Yayinlari, 1994), 22-6.

35 Jbid., 81.
} 
since been tried and sentenced to prison for fifteen years for engaging in activities against the political unity of the Turkish state. Second, despite the recruitment of more professional, modern women into the ranks of the party, they have not been included in the party lists and are not allowed to contest elections. Therefore, their raison $d^{\prime}$ etrewithin the party did not go any further than fostering a modern image for the RP. Third, RP's views concerning constitutional amendments geared towards further democratization in Turkey involved a rejection of most amendments not pertaining to a de-secularization of the regime. While on the one hand RP became more pragmatic with an urge to appeal to a wider constituency, it at the same time displayed statist tendencies in espousing a centralization of identities under an Islamic umbrella.

RP came out of the parliamentary elections that were held on December 24,1995 as the party with the plurality of the national votes $(21.38 \%)$. Therefore its MPs began to occupy the plurality of seats in the parliament. After months of deliberations among the center parties, RP founded a coalition government with the True Path Party (Dogru Yol Partisi) with RP's leader, Necmettin Erbakan, as Turkey's new Prime Minister. ${ }^{36}$ RP's role as the leading party in a coalition government, rather than being in opposition, brought to the surface a dilemma that is endemic to its discourse. After ascending to power, the RP leaders found themselves in a position where they could not challenge the legitimacy of the state system in Turkey, the parameters of which were defined in the course of the early years of the Republic. Yet, RP leadership simultaneously tried to sustain its appeal in the eyes of its constituency by making an Islamic identity visible in the public realm. This has paved the way to a paradox within the party discourse. In fact, some students of RP began to refer to a conflict between the discourses of the "political RP" and "sociological RP. ${ }^{37}$ In the course of its first year in government, RP leadership staggered between embracing the fundamental premises of the Republican regime, including secularism, on the one hand, and being extremely critical of it by adopting an Islamic identity, on the other. This, in turn, led to a polarization of the political climate in Turkey breeding essentialist identities such as militarist-secularist versus Islamist, and making it impossible to envision a democratic disclosure. The discourse of the RP has increasingly become more laden with motifs of the Republican epistemology, with its statist, central tendencies towards constructing an Islamic identity in a post-Kemalist medium.

\footnotetext{
36 This government received a vote of confidence in the parliament on July 8, 1996.

37 See, for instance. Menderes Cinar, "Postmodern Zamanlarin Kemalist Projesi: Türkiye'yi Refahlaştirmak," Birikim, no.91 (November 1996): 32-9.
} 
The arguments of the RP have always been based on a critique of the Kemalist modernization project. The Muslim intellectuals, on the contrary, forward a critique of modernity which goes beyond a critique of Kemalist secularization. Perhaps this is exactly the point which should be emphasized in distinguishing the Muslim intellectuals of the 1990s from their counterparts at the end of the nineteenth century. Those who opted for Islamism within the Young Ottoman thought at the end of the nineteenth century tried to reconcile Islam and Western modernity. The Muslim intellectuals in the 1990s have clearly abandoned attempts geared towards such a reconciliation. Theirs is a view of "the century through the lens of Islam rather than interpreting Islam through the lens of the modern era. " 38

Perhaps, one of the most debated projects associated with the Muslim intellectuals in Turkey is the Medina Contract, or Medina Constitution, brought to the forefront by Ali Bulac, who is considered one of the prominent Muslim intellectuals in Turkey. The Medina Contract was an accord between the Prophet Muhammad and other tribes of Medina at the time of the Asr-I Saadet (golden age of Islam). The contract was active between the years 622 to 632 . According to Bulaç, the Medina Contract is the legal documentation of a political unity. ${ }^{39}$ In a series of articles that have appeared in the course of the past three years, Bulac and many others debated the rejuvenation of the principles of the Medina Contract which made possible the livelihood of various groups with different religious convictions, secularists, and atheists in political unity. ${ }^{40}$ The contract was based on an idea of multiple judicial systems. In the course of the debates regarding the Medina Contract, it became clear that its proponents envisaged a critique of modernity and a return to religion. Bulaç, furthermore, located a special role for Islam, since he believed that neither Judaism nor Christianity could be a frame of reference in constituting a pluralist accord. ${ }^{41}$ According to Bulaç, Islam is the religion most conducive to paving the way to a pluralist accord.

In rejuvenating arguments towards a pluralist society with multiple judicial systems, Bulaç assigns a role to the Muslim intellectuals in eliminating Western influences on intellectual life while replacing them with

38 Cited in Binnaz Toprak, "Islamist Intellectuals: Revolt Against Industry and Technology," Metin Heper et al., Turkey and the West. Images of a New Political Culture (London, New York: I. B. Tauris and Co. Ltd. Publishers, 1993), 247-69, esp. 264.

39 Ali Bulaç, "Birarada Yaşamanin Mūmkūn Projesi: Medine Vesikasī," Bilgi re Bikmet 5 (1994): 5-16.

40 Most of the articles appeared in the journals Kitap, Birikim, Bilgi ve Hikmet between 1992-1995.

41 Ali Bulac,, "Dinlerin Meydan Okuyuşu: Entegrizm ve Fundamentalism," Birikim 37 (1992): 17-29. 
Qur'àn and Sunna. In stressing this, Toprak points to an element of vanguardism in Bulaç's thought. ${ }^{42}$

Michael Meeker analyzes the views of the three Muslim intellectuals, Ali Bulaç, Rasīm Ōzdenōren, and İsmet Ōzel. ${ }^{43}$ Since it is beyond the purposes of the current study to explore Muslim intellectuals in such a detailed manner, it will be useful to point to some of their common characteristics as they appear in Toprak's and Meeker's analyses.

First of all, the new Muslim intellectuals are very much a product of the secularist Turkish Republic. Some of them have attended secular educational institutions, have command over one or two Western languages, and refer to Western historiography extensively in their writings. Second, unlike their nineteenth century predecessors, the new Muslim intellectuals do not try to reconcile Islam and modernity, but rather they are critical of the premises of modernity itself. Third, when these two characteristics are combined, the new Muslim intellectuals can be distinguished by their critique of modernity along with numerous references to Western historiography. Perhaps, it is at this point that the language of the new Muslim intellectuals seem similar to a post-modern language. Yet, it is also very different. ${ }^{44}$ The new Muslim intellectuals seem very much trapped within the discursive and graphic practices firmly rooted in modernity. While, on the one hand, they seem to represent Islam as an alternative discourse, they resort to the discursive and graphic practices of another discourse, i.e. the modernization discourse in the Turkish context. Hence, their stance seems akin to the Westernists and secularists of the late Ottoman and early Republican period, who put the cart before the horse, i.e. who attempted to inculcate new ideas and new paradigms of thinking and behaving in an Islamic society in which the ethos of modernity had not taken root. The new Muslim intellectuals opt for the reconstitution of an Islamic way of life. In restoring Islam as an alternative discourse, they draw it into the polemical terrain of modernism.

Fethullah Gülen became well-known among the Muslim community in Turkey in the course of the 1970s as a preacher and a student of the school of Nurculuk, the origins of which go back to the works of Bediüzzaman Said Nursi (1873-1960). In the course of the past couple of years, Gülen and his community have acquired widespread media cover-

\footnotetext{
42 Binnaz Toprak, "Islamic Intellectuals," 259.

43 Michael Meeker, "The New Muslim Intellectuals in the Republic of Turkey," ed., Richard Tapper, Islam in Modern Turkey: Religion, Politics and Literature in a Secular State (London, New York: I. B. Tauris and Co. Ltd. Publishers, n.d.), 189-219.

44 In order to further clarify the difference of Ali Bulaç's stance from a post-modern politics of difference, see Menderes Cinnar and Ayşe Kadioğlu, "An Islamic Critique of Modernity in Turkey: Politics of Difference Backwards (Ankara, Turkey: Bilkent University, unpublished manuscript, 1996).
} 
age in Turkey. This is partly because of the popularity of a newspaper, Zaman, and a television channel that seem to have become the voice of this community's new vocation within the Turkish political structure. ${ }^{45}$

Gülen and his community represent what could be called "moderate Islam" in the Turkish context. Gülen usually uses words like consensus, compromise, dialogue in his statements. According to him, women's headgear and the necessity to cover certain parts of the body in Islam are more trivial issues than they have come to represent in the Turkish context. Gülen has been critical of the focus of the debates in Turkey regarding Islam around such issues. He has referred to "globalization" in his statements by which he implies a dialogue among the representatives of other world religions. Gülen does not have a world view that is situated against other world views. For instance, he does not represent an antiUnited States, nor an anti-Europe position. He seems to have freed himself from such convictions of the cold war era. Perhaps one of the most significant aspects of Gūlen's views has been revealed in his statements regarding Atatūrk. Gūlen's statements about Atatürk are full of praise for his wit, intellect, and leadership. In fact, he refers to Atatürk as a genius. Not surprisingly, Gülen's views about Atatürk have attracted a great deal of popularity in a country that has been divided into a secularist and an Islamic camp in the course of the past decade and a half. While the latter have begun to march in the streets in Islamic attire, the former have been busy commercializing the image of Atatūrk. Atatürk pins, necklaces, bumper stickers. . . etc. , have become quite widespread in Turkey in the 1990s. In a country divided around the cult of a personality, with Atatürk bashers on the one side, and Atatürk lovers on the other, when a wellknown Islamic preacher calls him a genius, this evidently earns him a lot of popularity.

Gülen opts for combining religious and modern education. His supporters have established hundreds of schools in Turkey and in countries like the United States, Albania, Georgia, and Moldavia towards that end. He has questioned the West's exclusive rights over modernity. He has opened up a debate about the possibility of an Islamic Enlightenment. While he is open to the science and technology of the West, he also represents the emotionalism of the East. ${ }^{46}$ As Can Kozanoğlu puts it, in the current climate of a "cultural open buffet" in Turkey, Gūlen's plate is full of various dishes, i.e., identities, some of which do not go well together. ${ }^{47}$

45 Zaman has recently published a series of interviews with Fethullah Gülen. Eyüp Can, "Fethullah Gülen Hocaefendi lle Ufuk Turu," Zaman, August 13-23, 1995. Those interviews and their evaluations by Turkish academics, and intellectuals, which appeared in the newspapers Zaman and Cumhurjyet, constitute the basis of this study's evaluations regarding Fethullah Gūlen and his community.

46 Fethullah Gülen is famous for crying while preaching.

47 Can Kozanoğlu, "Düzenle Uyumlu, Aldatīci Seffaflik,," Cumhurijet, August 24, 1995. 
These are Westernism, localism, Easternism, secularism, Islamism, modernism, nationalism and Turkism.

It is possible to view the embracing of such multiple identities as a sign of a pragmatism on Gūlen's part. In fact, many analyses, referring to the statist and militarist themes in his discourse, see him and his community as a pragmatist group which gives the economic and political elite in Turkey an Islamic identity. Gülen's statements are filled with praises for the state and especially for the military. He does not condone rebellion against such authorities. ${ }^{48} \mathrm{He}$ preaches obedience.

It is not surprising that Gūlen's ideas have been embraced by various, sometimes opposing camps in Turkey. This is because he has something for each one of them on his big plate which he filled from the cultural open buffet. Fethullah Gülen is one of the latest and most popular modern Muslims that Republican Turkey has produced. Interestingly, RP leadership is the most outspoken critic of Gūlen's views. ${ }^{49}$

While $R P$ is busy reducing tradition to Islam in its adamant critique of modernization in the Turkish context, Gülen opens up new avenues for the future in pointing to a cultural continuity with a past that involves elements other than Islam. Yet, while espousing cultural continuity, Gülen is paradoxically embracing a centralized, militarist state tradition. It is at this point that his views are haunted by a dilemma. It does not seem possible to restore a cultural continuity with the past while simultaneously embracing a Republican state tradition since it is the latter that had made the former impossible. In other words, it was the Republican, centralized, state tradition which prompted a rupture from the Ottoman past with its Islamic and other features. Yet, despite all such paradoxes that it contains, it looks like Gülen and his community, with all their pragmatism and mystic features, will continue to garner further interest in Turkey from various groups.

48 At this point, his views display a continuity with Bediüzzaman Said Nursi who was critical of the 1925 Seyh Sait rebellion. See Cakir, Ayet re Slogan, 80.

49 See Ismail Nacar's views, for instance in Cumburjyet, Ismail Nacar, "Durmadan Ağlayan Adam," Cumburiyet (August 22, 1995). Nacar argues that Fethullah Gūlen's "small world" (the title of Fethullah Gülen's book, Küfük Dünyam-My Small World) is not so small, since he claims that he comes from the Prophet's family. Nacar is also critical of Gülen's statements which imply a special mystical status for himself, such as the story about not being stung by insects, the destruction of his neighbors garden by a heavy rain once when none of the surrounding gardens were hit (that neighbor had hit and crippled some of Gülen's family's animals implying that he was penalized by an high authority)... etc. It is true that Gülen has carved out a special status for himself by such statements involving some extraordinary/mystic incidents. But, what is more interesting is how such statements are portrayed as ridiculous by an Islamic political party. Nacar believes that Gülen is serving the interests of the True Path Party and is giving it an Islamic flavor. This, in turn, is against the interests of the RP that had a monopoly over Islamic motifs within a political party structure. 


\section{Conclusions}

Ottoman encounters with the West were such that they prompted the emergence of dual structures within Tanzimat thought. While trying to preserve a decadent empire, Ottoman statesmen at the turn of the nineteenth century embraced the idea of progress and Westernism. The idea of Westernism involved the positioning of the Ottoman Self in reference to a privileged Other, i.e. the West. While the nationalist ideologies were accompanying the transition to modern politics in the West, with nationstates as the main actors, this was inciting the Ottoman intellectuals to construct new, modern identities for themselves. The efforts of the Republican elite were geared towards a much more pronounced Westernization project. The Republican elite, whose ideas were laden with positivist motifs, launched a modernization project from above. The modern idea of progress became an end for them, rather than a means for preserving the state. They believed that Islam, and the traditional culture that it nurtured, was the main cause of the backwardness and problems of the empire. Hence, they adopted a view of order for the sake of progress, as opposed to the Tanzimat statesmen who gave in to progress for the sake of order, for preserving a decadent empire. This urged the Republican elite to adopt a policy of secularization which was largely teleological, and perhaps somewhat theological.

In the course of this process of modernization tailored within the Turkish context, it is possible to observe an epistemology based on essentialism and social engineering. It is obvious that all modern entities have elements of constructedness in them. Yet, what distinguishes the modernization context is an attempt to sever links with the past. This instilled a state of amnesia in Republican Turkey. The Republican epistemology embodied vanguardism, elitism, statism, managerialism, and militarism.

The Young Ottomans who were educated in modern, Western institutions were interested in placing some limits to modernization at the end of the nineteenth century. Since the Tanzimat statesmen had already put the cart before the horse by starting a series of institutional reforms in a society in which the ethos of modernity had not taken root, the intellectuals had taken upon themselves the responsibility to cultivate that ethos in an Islamic society. By portraying modest-yet-modern fictional characters in their novels, the men of letters of the Tanzimat era tried to construct a modern identity laden with Islamic motifs. The vanguardism of the Tanzimat statesmen as well as the cultural elites of the period was accentuated during the Republican years. The vanguardism of the cultural elite at the end of the nineteenth century was personified in the fate of Beşir Fuad, a prominent novelist, who committed suicide in 1887 and took notes while he died in order to contribute to the zeal of the novelists of his time, 
i.e. the conception of the modern, experimental novel. ${ }^{50}$ The Republican elite continued the trend of putting the cart before the horse that had begun with the Tanzimat reforms. They tried to inculcate the birth of modern institutions before the emergence of modern ideas which demanded them. Perhaps, it is possible to point to a similarity between the fates of Beşir Fuad and the Turkish Republican elite, since they both cultivated the seeds of their own finale by their altruistic positivism.

Islamic discourses of the 1990s display various characteristics. This fact reveals analyses which refer to the threat of a monolithic Islamic fundamentalism to be rather artificial. The three Islamic groups and their discourses portrayed above reveal an increasing significance of modern elements in them. All of these currents seem to have received their share of the Republican epistemology.

Islamic discourses in the 1990s in Turkey have clearly prompted debates on identity. They have challenged the foundations of a monolithic, absolute, official Republican Turkish identity. Nevertheless, their analyses did not urge a shift of focus from identities to differences, unities to fragmentations, and presences to absences. Islamic discourses are cultivating post-modern themes within a modernist context. This, in turn, is paving the way towards an explosion of identities in Turkey expressed in modern concepts such as ethnicity, culture, nation, religion, and tradition. The predominance of the key features of the Republican epistemology such as essentialism and managerialism seems to obstruct possibilities for a democratic disclosure in Turkey. Could it be that, in their current state, the Islamic discourses which bring the question of identity to the forefront in Turkey are putting the cart before the horse since they raise the question of identity in a modern context prior to an epistemological transformation?

Bilkent University

AYşe KADIOǦLú

Ankara, Turkey

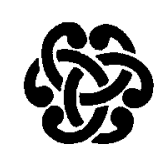

50 See, Jale Parla on putting the cart before the horse in the Tanzimat novel. Jale Parla, Babalar ve Ogullar: Tanzimat Romaninin Epistemolojik Temelleri (Istanbul: lletisim Yayinlari, 1990). 